\title{
Infestation Maps and Spatial Stability of Main Weed Species in MAIZe CUlTURE ${ }^{1}$
}

\author{
Mapas de Infestação e de Estabilidade Espacial de Infestantes da Cultura do Milho \\ CALHA, I.M. ${ }^{2}$, SOUSA, E. ${ }^{3}$, and GONZÁLEZ-ANDÚJAR, J.L. ${ }^{4}$
}

\begin{abstract}
A study on the spatial distribution of the major weeds in maize was carried out in 2007 and 2008 in a field located in Golegã (Ribatejo region, Portugal). The geo-referenced sampling focused on 150 points of a $10 \times 10$ m mesh covering an area of 1.5 ha, before herbicide application and before harvest. In the first year, 40 species (21 botanical families) were identified at seedling stage and only 22 during the last observation. The difference in species richness can be attributed to maize monoculture favouring reduction in species number. Three of the most representative species were selected for the spatial distribution analysis: Solanum nigrum, Chenopodium album and Echinochloa crus-galli. The three species showed an aggregated spatial pattern and spatial stability over both years, although the herbicide effect is evident in the distribution of some of them in the space. These results could be taken into account when planning site-specific treatments in maize.
\end{abstract}

Keywords: geo-statistics, kriging, precision agriculture, Chenopodium album, Echinochloa crus-galli, Solanum nigrum

\begin{abstract}
RESUMO - Analisou-se a distribuição e estabilidade espacial de Chenopodium album, Echinochloa crus-galli e Solanum nigrum em um campo de milho do Ribatejo (Portugal) durante os anos de 2007 e 2008. A amostragem georreferenciada incidiu sobre 150 pontos em uma malha de $10 \times 10 \mathrm{~m}$, cobrindo uma área de 1,5 ha, antes da aplicação de herbicidas e antes da colheita. No primeiro ano foram identificadas 40 espécies (21 famílias botânicas), em fase de plântula; no final do segundo ano, apenas 22. A diferença no número de espécies pode ser atribuida à monocultutra de milho, que contribui para a redução da riqueza especifica. As três espécies mais representativas foram analisadas mediante um estudo geoestatístico, o que permitiu determinar o grau de variabilidade espacial e obter mapas de infestação por kriging baseados nos modelos que melhor se ajustavam a cada caso. Os resultados mostraram estabilidade espacial em todos os casos, exceto para C. album e S. nigrum em um dos periodos de tempo. Esses mapas, em conjunto com a estabilidade espacial geral registrada para as três espécies, são úteis para desenvolver programas de aplicação localizada de herbicidas, visando reduzir o impacto ambiental do recurso a esses produtos fitofarmacêuticos.
\end{abstract}

Palavras-chave: geoestatística, kriging, agricultura de precisão, Chenopodium album, Echinochloa crus-galli, Solanum nigrum.

\section{INTRODUCTION}

Weeds are usually aggregated in patches within the crop (Wiles et al., 1992; GonzalezAndujar and Saavedra, 2003). This is important from the point of view of management because herbicide use could be reduced by spraying only patches with weed infestation or by adjusting herbicide rate (Barroso et al., 2004). In order to implement localized applications, it is necessary to know the spatial distribution map of the weed species, either identifying emerged weed flora or weed seed banks (Monquero et al., 2008; Izquierdo et al., 2009). Due to the high cost associated with the generation of these maps is important to

Recebido para publicação em 1.7.2013 e aprovado em 6.12.2013.

2 Instituto Nacional de Investigação Agrária e Veterinária, Oeiras, Portugal, <isabel.calha@iniav.pt $>$; ${ }^{3}$ Instituto Superior de Agronomia, Lisboa, Portugal; ${ }^{4}$ Instituto de Agricultura Sostenible Córdoba, España. 
minimize the frequency of the mapping, therefore, the spatial and temporal stability of the weed patchs is critical. Species with a stable spatial distribution will no require the frequent generation of new maps (Barroso et al., 2006; Longchamps et al., 2012).

The aim of this study was to analyze the spatial distribution and spatio-temporal stability of the main weed species present in a maize field, using geostatistical techniques.

\section{MATERIAL AND METHODS}

The sample plot was situated in Golegã (Ribatejo) (4380373N, 467433E) in Portugal, with an area of 2.5 ha of which 1.5 ha was sampled with a total sample taking of 150 points (each point with an area of $10 \mathrm{~m} \times 10 \mathrm{~m}$ ) (Figure 1). The plot was under a beet-maize rotation, with maize planted in 2007 and 2008, when the sampling was made. Samples (seedlings plants $\mathrm{m}^{-2}$ ) were taken twice per year, one at the beginning of the cropping season (before herbicide application) and at its end (one week before harvest). Sampling points were georeferenced. Weed control in 2007 was conducted in postemergence (before completion of sampling) with atrazine, sulfonylureas, and bromoxynil. In the subsequent campaign, the herbicide treatment for weed control was sprayed again. Atrazine-resistant populations of Chenopodium album were present in the field.

A relative importance index (RI) was calculated for the major species for each sampling time, as $\mathrm{RI}=(\mathrm{rD}+\mathrm{rF}) / 2$, where $\mathrm{rD}$ is the relative density and $\mathrm{rF}$ is the relative frequency (absolute frequency of each weed/ total absolute frequency of all weeds) (Derksen et al., 1993)

Geoestatistical techniques (GonzalezAndújar et al., 2001; Jurado-Exposito et al., 2003; López-Granados, 2011) were used to describe and to map the spatial distribution of Echinochloa crus-galli, Chenopodium album and Solanum nigrum. A cross-validation procedure was performed to check model validity.

In order to determine the spatiotemporal stability, the statistical test proposed by Syrjala (1996) was used to detect whether the spatial distribution of the population has changed over time. The null hypothesis was that there was no difference in the spatial distributions of two populations against the alternative hypothesis that some unspecified difference existed between the two distributions. This test is specifically designed to be insensitive to differences in the total abundances in the study area, but sensitive to differences in the distributions given the relative sizes of the two populations. The statistic to test the null hypothesis is the square of the difference between the two cumulative distribution functions, summed over all sampling locations, that is:

$$
\Psi=\sum_{k=1}^{k}\left[\Gamma_{1}\left(x_{k}, y_{k}\right)-\Gamma_{2}\left(x_{k}, y_{k}\right)\right]^{2}
$$

where $\Gamma_{i}\left(x_{k}, y_{k}\right)$ is the cumulative distribution function for the $i$ population at the $k$ sampling location and is defined as:

$$
\Gamma_{1}\left(x_{k}, y_{k}\right)=\sum_{\forall x \leq x_{k}, \forall y \leq y_{k}} y_{i}(x, y)
$$

\section{2)}

where $\Sigma \Gamma_{i}(x, y)$ is the sum of all normalized density observations, whose location $(x, y)$ is such that $x \leq x_{k}$ and $y \leq y_{k}$, see Eqn 3 .

$$
\begin{aligned}
& y_{i}\left(x_{k}, y_{k}\right)=\frac{d_{i}\left(x_{k}, y_{k}\right)}{D_{i}} \\
& D_{i}=\sum_{k=1}^{k} d_{i}\left(x_{k}, y_{k}\right)
\end{aligned}
$$

where being $d_{i}\left(x_{k}, y_{k}\right)$ the value of the weed species density in a given sampling point $\left(x_{k}, y_{k}\right)$, for the $i$ population and $D_{i}$ the sum of all density observations for that species, which defines the normalized density observation.

\section{RESULTS AND DISCUSSION}

Fourty taxa were recorded and distributed over 21 families with predominance of Poaceae, Asteraceae and Caryophyllaceae. Eighty six percent of all species were annuals. Eighteen species were present on both years. Table 1 shows the relative importance index of the species evaluated in post-crop emergence, 
Table 1 - Prevailing life cycle and relative importance index (rI) of weed species during two growing seasons (2007 and 2008$)$

\begin{tabular}{|c|c|c|c|c|c|c|c|}
\hline Species & BAYER code & Botanical family & Life cycle & $\begin{array}{l}\text { May } \\
2007\end{array}$ & $\begin{array}{l}\text { Sep. } \\
2007\end{array}$ & $\begin{array}{l}\text { May } \\
2008\end{array}$ & $\begin{array}{l}\text { Sep. } \\
2008\end{array}$ \\
\hline Abutilon theophrasti Medicus & ABUTH & Malvaceae & annual & 5.8 & 1.6 & 4.7 & 1.1 \\
\hline Amaranthus blitoides S. Watson & AMABL & Amarantaceae & annual & 1.8 & 0.8 & 0.0 & 0.0 \\
\hline Amaranthus deflexus $\mathrm{L}$. & AMADE & Amarantaceae & annual & 5.5 & 6.1 & 20.5 & 27.4 \\
\hline Ammi majus $\mathrm{L}$. & AMIMA & Apiaceae & annual & 1.0 & 1.0 & 0.9 & 0.0 \\
\hline Anagallis arvensis $\mathrm{L}$. & ANGAR & Primulaceae & annual & 5.1 & 1.3 & 0.0 & 0.0 \\
\hline Atriplex patula $\mathrm{L}$. & ATPPA & Chenopodiaceae & annual & 0.8 & 0.0 & 0.0 & 0.0 \\
\hline Beta vulgaris $\mathrm{L}$. & BEAVX & Chenopodiaceae & annual & 2.6 & 1.0 & 1.0 & 0.0 \\
\hline Cerastium glomeratum Thuill. & CERGL & Caryophyllaceae & annual & 0.0 & 0.0 & 1.3 & 0.0 \\
\hline Chenopodium album $\mathrm{L}$. & CHEAL & Chenopodiaceae & annual & 6.6 & 3.1 & 5.1 & 3.1 \\
\hline Convolvulus arvensis $\mathrm{L}$. & CONAR & Convolvulaceae & perennial & 1.7 & 0.9 & 0.7 & 1.5 \\
\hline Conyza bonariensis (L.) Cronq. & ERIBO & Asteraceae & annual & 0.0 & 1.4 & 0.0 & 0.0 \\
\hline Cynodon dactylon (L.) Pers. & CYNDA & Poaceae & perennial & 0.8 & 0.0 & 0.7 & 0.8 \\
\hline Cyperus esculentus $\mathrm{L}$. & CYPLO & Cyperaceae & perennial & 1.0 & 0.0 & 0.0 & 0.0 \\
\hline Cyperus longus $\mathrm{L}$. & CYPLO & Cyperaceae & perennial & 0.0 & 0.0 & 0.0 & 0.0 \\
\hline Cyperus rotundus $\mathrm{L}$. & CYPLO & Cyperaceae & perennial & 1.4 & 0.0 & 0.3 & 0.0 \\
\hline Datura stramonium L. & DATST & Solanaceae & annual & 5.9 & 2.2 & 3.8 & 3.8 \\
\hline Digitaria sanguinalis (L.) Scop. & DIGSA & Poaceae & annual & 3.4 & 4.0 & 4.2 & 3.9 \\
\hline Diplotaxis catholica (L.) DC. & DIPCA & Brassicaceae & annual & 1.8 & 0.6 & 3.3 & 0.0 \\
\hline Echinochloa crus-galli (L). P. Beauv. & ECHCG & Poaceae & annual & 7.0 & 6.7 & 14.7 & 23.8 \\
\hline Kickxia spuria $(\mathrm{L}$.$) Dumort.$ & KICSI & Scrophulariaceae & annual & 3.1 & 1.5 & 0.5 & 0.0 \\
\hline Lamium purpureum $\mathrm{L}$. & LAMPU & Lamiaceae & annual & 0.5 & 0.0 & 0.0 & 0.8 \\
\hline Oxalis acetosella $\mathrm{L}$. & OXACO & Oxalidaceae & annual & 0.0 & 0.0 & 0.9 & 1.7 \\
\hline Oxalis corniculata $\mathrm{L}$. & OXAPC & Oxalidaceae & annual & 1.4 & 9.6 & 0.8 & 0.0 \\
\hline Picris echioides $\mathrm{L}$. & PICEC & Asteraceae & biennial & 0.6 & 1.0 & 0.4 & 0.8 \\
\hline Piptaterum miliaceum (L.) & ORZMI & Poaceae & perennial & 0.5 & 0.5 & 0.0 & 0.0 \\
\hline Plantago major L. & PLAMA & Plantaginaceae & perennial & 0.5 & 0.0 & 0.0 & 0.0 \\
\hline Poa aпnиа $\mathrm{L}$. & POAAN & Poaceae & annual & 0.9 & 20.2 & 4.8 & 11.9 \\
\hline Polycarpon tetraphyllum (L.) L. & POYTE & Caryophilaceae & annual & 3.3 & 3.3 & 0.5 & 0.0 \\
\hline Polygonum persicaria $\mathrm{L}$. & POLPE & Polygonaceae & annual & 0.0 & 0.0 & 0.2 & 0.0 \\
\hline Portulaca oleracea $\mathrm{L}$. & POROL & Portulacaceae & annual & 0.5 & 0.6 & 0.7 & 0.0 \\
\hline Pseudognaphalium luteo-album (L.) Hilliard & & Asteraceae & annual & 0.0 & 0.0 & 0.0 & 0.4 \\
\hline Ranunculus muricatus $\mathrm{L}$. & RANMU & Ranunculaceae & annual & 1.9 & 0.6 & 0.8 & 0.0 \\
\hline Ranunculus trilobus Desf. & RANTB & Ranunculaceae & annual & 1.0 & 1.0 & 3.5 & 0.0 \\
\hline Rumex crispus $\mathrm{L}$. & RUMPC & Polygonaceae & perennial & 0.9 & 2.2 & 0.7 & 0.0 \\
\hline Rumex pulcher L. & RUMCR & Polygonaceae & perennial & 1.4 & 0.8 & 0.5 & 0.0 \\
\hline Setaria verticillata (L.) P. Beauv. & SETVE & Poaceae & annual & 0.0 & 0.0 & 7.5 & 1.9 \\
\hline Solanum nigrum L. & SOLNI & Solanaceae & annual & 13.9 & 8.5 & 0.6 & 5.1 \\
\hline Sonchus asper (L.) Hill & SONAG & Asteraceae & biennial & 2.3 & 2.5 & 9.8 & 0.0 \\
\hline Sonchus oleraceus L. & SONOL & Asteraceae & biennial & 6.2 & 9.8 & 0.4 & 7.3 \\
\hline Sorghum halepense (L.) Pers. & SORHA & Poaceae & perennial & 0.0 & 0.0 & 0.0 & 0.8 \\
\hline Spergula arvensis $\mathrm{L}$. & SPRAR & Caryophyllaceae & annual & 0.5 & 0.5 & 1.1 & 0.0 \\
\hline Stellaria media (L.) Vill. & STEME & Caryophyllaceae & annual & 0.8 & 3.1 & 0.0 & 1.8 \\
\hline Trifolium campestre Schreber & TRFCA & Fabaceae & annual & 0.5 & 0.5 & 0.6 & 0.0 \\
\hline Verbena officinalis L. & VEBOF & Verbenaceae & perennial & 0.8 & 0.8 & 3.8 & 0.0 \\
\hline Veronica persica Poiret & VERPE & Scrophulariaceae & annual & 4.2 & 3.9 & 0.3 & 2.6 \\
\hline Xantium strumarium L. & XANST & Asteraceae & annual & 2.1 & 0.0 & 0.0 & 0.0 \\
\hline \multicolumn{4}{|l|}{ Total density (seedlings $\mathrm{m}^{-2}$ ) } & 113 & 64 & 236 & 71 \\
\hline
\end{tabular}


the first of May (before application of herbicide) and the second of September (one week before harvest) for 2007 and 2008 . Considering only the most important species (rI $>1$ ) in 2007, the number of species was higher, 25-22 from May to September and the total density in the first observation was lower (113 seedlings $\mathrm{m}^{-2}$ ) than in 2008 . In the latter, the number of species from May to September and the total density were $15-14$ species and 236 seedlings $\mathrm{m}^{-2}$, respectively (Table 1 ). A modification of the cropping system from crop rotation (beet-maize) to maize monocropping could explain the decline in diversity from 2007 to 2008 .

The three most abundant species (over 100 seedlings $\mathrm{m}^{-2}$ ) during the first cropping season were E. crus-galli C. album and S. nigrum. These results are in accordance with studies in maize crops in different areas from Spain and Portugal (Dorado et al., 2009).

The spatial distribution of E. crus-galli, C. album and S. nigrum was analysed and different models were fitted to each weed species (Table 2). There was no evidence of directional effect (anisotropy) in accordance with Halstead et al. (1990) and Cardina et al. (1995).

The results indicate that the three species showed an aggregated spatial distribution with varying degrees of spatial dependence over time. The nugget, the sill and the range varied among species and within species between different sampling times (Table 2) possibly due to the effect of herbicide action.

The three weed species declined significantly during the last season, particularly $C$. album and S. nigrum. For the last sampling, made at the end of the cropping season of 2008, populations of C. album and $S$. nigrum virtually disappeared because of herbicide action.

A decrease in weed density of $70 \%$, between the first and second observation, was registed in 2008 and could be attributed to herbicide efficacy. Weed density within the year decreased from 236 seedlings $\mathrm{m}^{-2}$, before herbicide application, to 71 seedlings $\mathrm{m}^{-2}$ at harvest. The C. album population was resistant to atrazine and two herbicides were applied in post-emergence to increase control.

C. album patches were located mainly next to field margins and remained considerably stable across the period of two years of study (Figure 1). The concentration of patches near field edges is common in maize fields (Colbach et al., 2000) and could be attributed to seed emigration, lower levels of crop establishment and poor control in these areas.

S. nigrum showed a large decline in population at the end of the second cropping season following the herbicide application, which could significantly affect their spatial distribution (Figure 3).

Table 2 - Semivariograms ajusted to data for major maize weed species at different sampling dates

\begin{tabular}{|l|l|l|c|c|c|c|}
\hline Species & Date & Fitted Model & Nugget & Sill & Range (m) & RSS \\
\hline \multirow{5}{*}{ Echinochloa crus-galli } & May 07 & Linear Model & 0.571 & 0.751 & 2262 & 0.0084 \\
& Sep. 07 & Gaussian Model & 0.312 & 0.810 & 2193 & 0.0049 \\
& May 08 & Exponential Model & 0.746 & 1.493 & 1651 & 0.0237 \\
& Sep. 08 & Exponential Model & 0.669 & 1.339 & 612 & 0.0409 \\
\hline \multirow{5}{*}{ Chenopodium album } & May 07 & Spherical Model & 0.408 & 1.069 & 866 & 0.0397 \\
& Sep. 07 & Spherical Model & 0.163 & 0.327 & 827 & 0.0109 \\
& May 08 & Exponential Model & 0.087 & 1.020 & 116 & 0.0661 \\
& Sep. 08 & Exponential Model & 0.008 & 0.059 & 71 & 0.0002 \\
\hline \multirow{5}{*}{ Solanum nigrum } & May 07 & Gaussian Model & 0.089 & 0.509 & 135 & 0.0141 \\
& Sep. 07 & Exponential Model & 0.095 & 0.689 & 88 & 0.0200 \\
& May 08 & Spherical Model & 0.412 & 0.825 & 520 & 0.0248 \\
& Sep. 08 & Spherical Model & 0.013 & 0.142 & 132 & 0.0007 \\
\hline
\end{tabular}

Nugget - the y-intercept of the model; Sill - the model asymptote; Range - the separation distance over which spatial dependence is apparent; RSS - Residual Sums of Squares. 


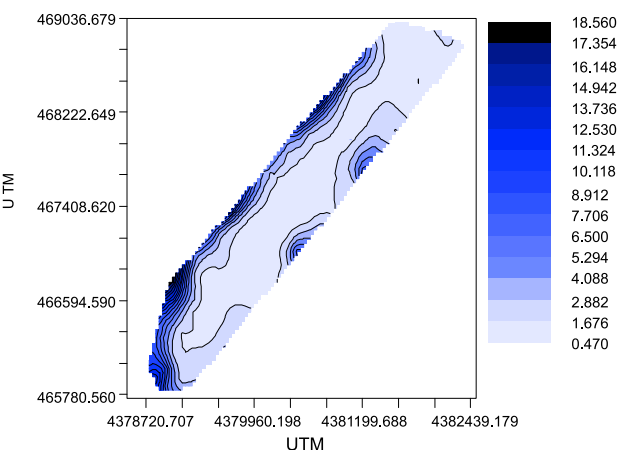

May 2007

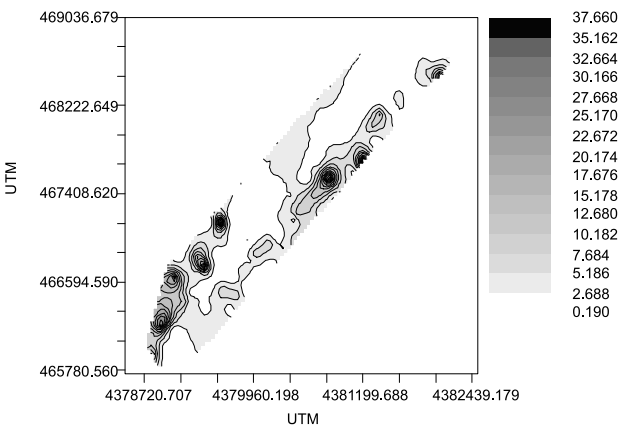

May 2008

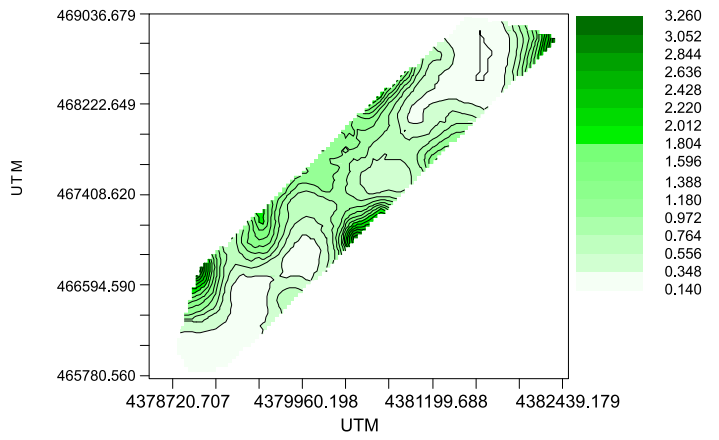

Sept 2007

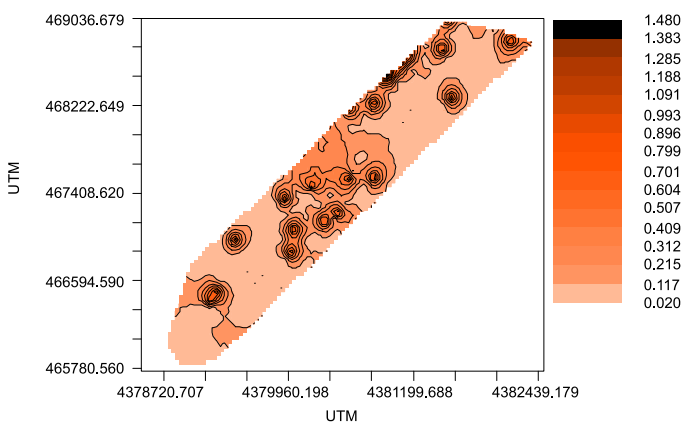

Sept 2008

Figure 1 - Isoline kriged maps of Chenopodium album density (seedlings m²) in 2007 and 2008.

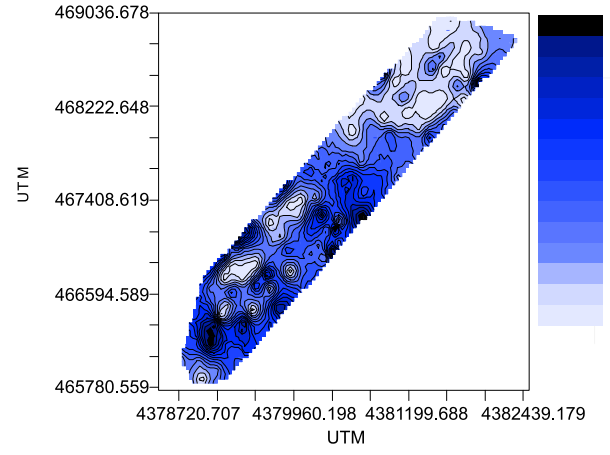

May 2007

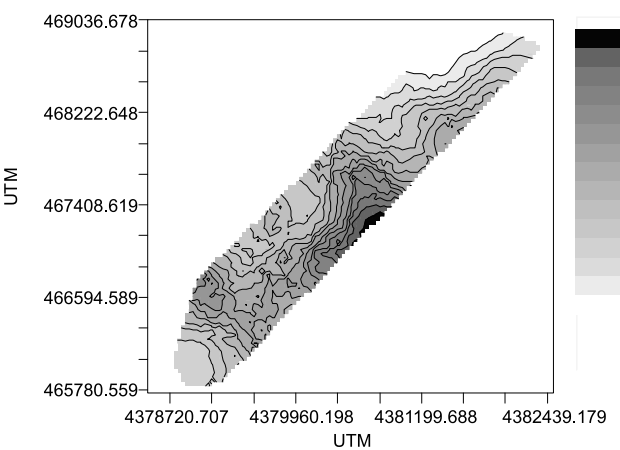

May 2008

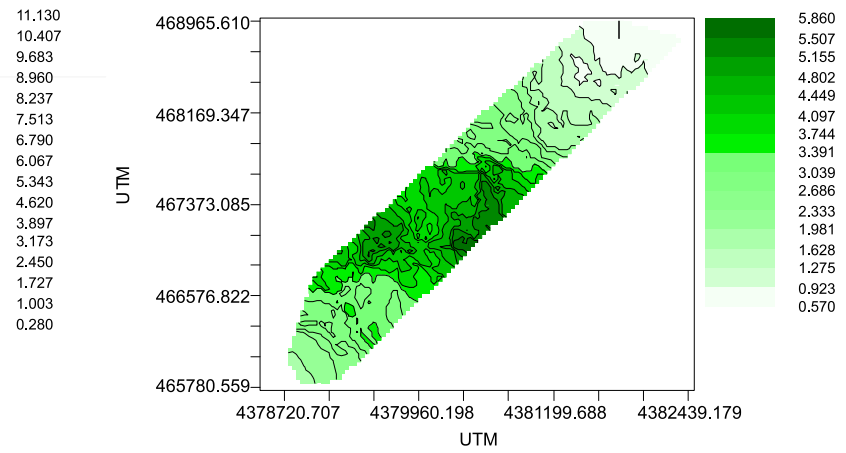

Sept 2007

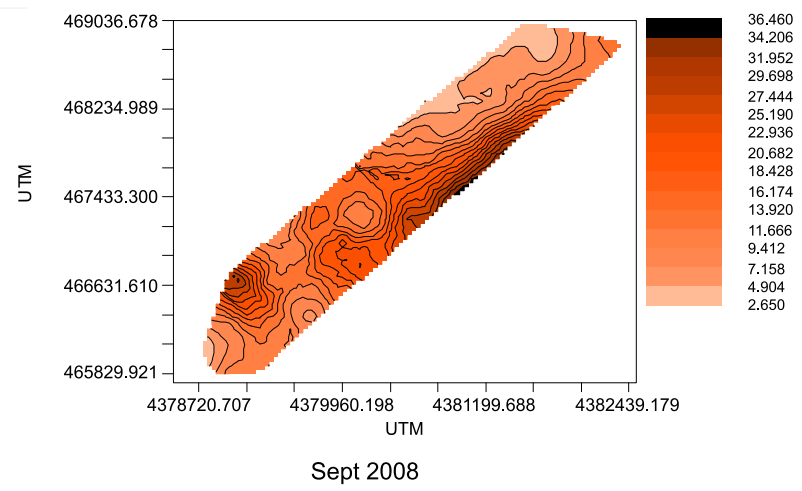

Figure 2 - Isoline kriged maps of Echinochloa crus-galli density (seedlings m²) in 2007 and 2008. 

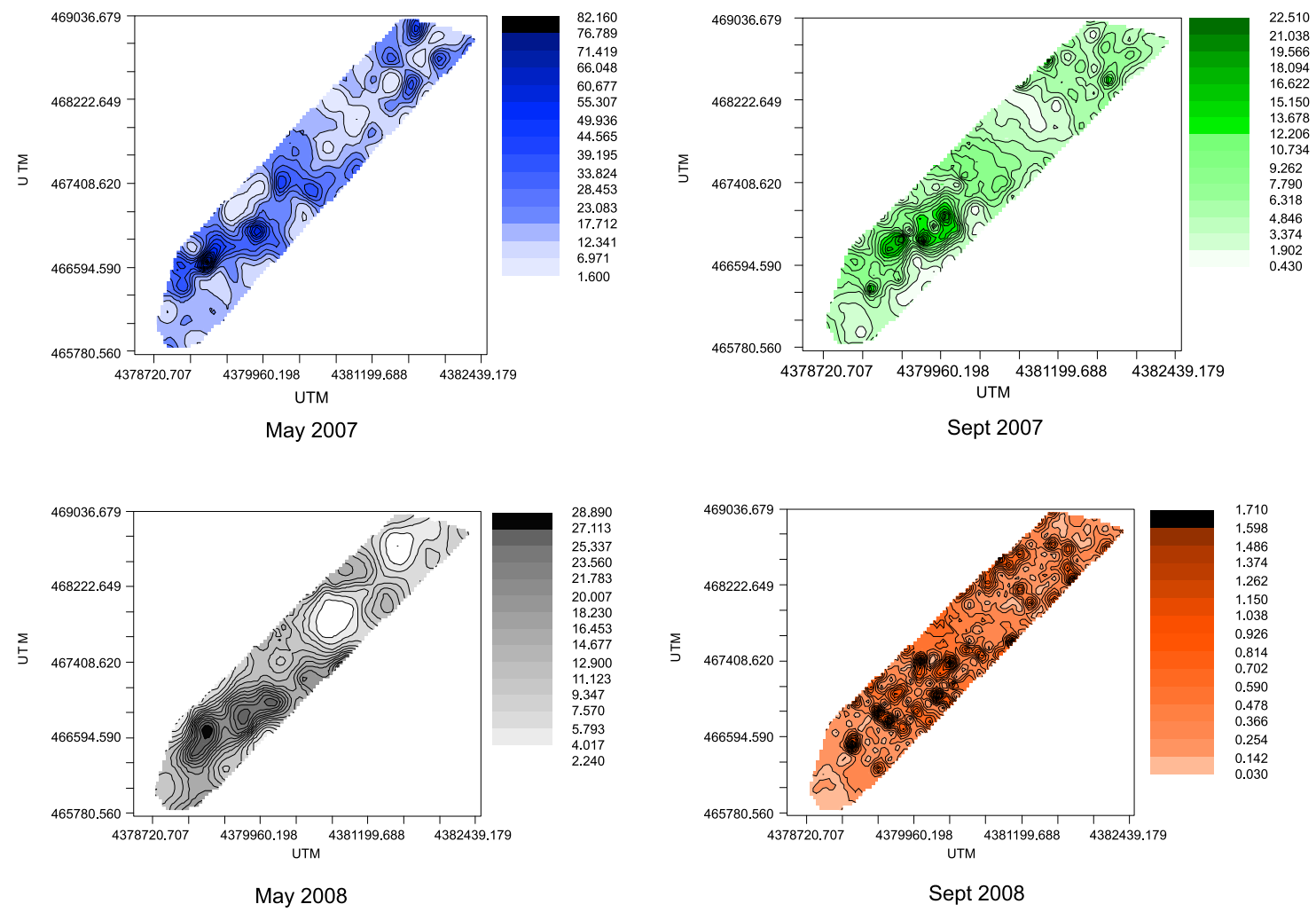

Figure 3 - Isoline kriged maps of Solanum nigrum density (seedlings m²) in 2007 and 2008.

The success of E. crus-galli (Figure 2) may be attributed to the production of large numbers of small, easily dispersed seeds per plant, possession of seed dormancy, rapid ability to flower under a wide range of photoperiods and relative tolerance of mature seeds to herbicide application (Maun \& Barret, 1986).

By using the Syrjala's test to evaluate spatial and temporal persistence (Table 3), it can be conclude that E. crus-galli showed within and between years spatial stability. C. album showed spatial stability in the two last time periods and $S$. nigrum in the two first time periods (Table 3 ). It should be noted that the three species showed spatial stability between years (September 07/May 2008). The results of patch persistence over time vary between species depending on their bioecological characteristics, but need to be combined with weed management practices in the field, such as herbicide application and direction of machine work at cultivation and harvesting or soil fertility (Shiratsuchi et al., 2005).

Planta Daninha, Viçosa-MG, v. 32, n. 2, p. 275-282, 2014
In general, patch persistence is greater for perennial (S. nigrum) compared to annual weed species (C. album and E. crus-galli). However, some annuals with high seed production such as Alopecurus myosuroides is also spatially stable. This pattern could be due to the use of effective herbicides that do not allow weeds to produce seeds and contribute to restrain the dispersion of weed seed across the field.

In general, the three species showed spatiotemporal stability, suggesting that weed seedling distribution mapped in the first year are good predictors of future seedling distributions. This can open the door to use site-specific weed management for these species in maize in Portugal. Further studies are needed in Mediterranean conditions to allow for site-specific application of selective herbicides in the field. Recent technology using gadgets such as small unmanned aircraft systems (UAS) could contribute to the cost-effectiveness of sampling methods, one of the main constrains to practical application of mapping to weed management (Zhang \& Kovacs, 2012; Ramussen et al., 2013). 
Table 3 - Comparison of sample maps for the three main weed species according to statistics $\varphi$ (Syrjala test)

\begin{tabular}{|l|c|c|c|}
\hline \multicolumn{1}{|c|}{ Species } & May-Sep. 07 & Sep. 07-May 08 & May-Sep. 08 \\
\hline Echinochloa crus-galli & $0.185 \mathrm{~ns}$ & $0.158 \mathrm{~ns}$ & $0.693 \mathrm{~ns}$ \\
\hline Chenopodium album & $1.505^{*}$ & $0.972 \mathrm{~ns}$ & $2.063 \mathrm{~ns}$ \\
\hline Solanum nigrum & $0.069 \mathrm{~ns}$ & $0.239 \mathrm{~ns}$ & $2.124^{* *}$ \\
\hline
\end{tabular}

ns: No significatant; *: significant $(\mathrm{P}>0.05)$; ** significant $(\mathrm{P}>0.001)$.

Echinochola crus-galli, Chenopodium album and Solanum nigrum were the main weeds found in the first year of study in the maize field, although the last two suffered a drastic decline during time and almost have disappeared after the second year. The three species showed an aggregated spatial pattern and showed spatial stability over both years, although the herbicide effect is evident in the distribution of some of them in space. These results could be taken into account when planning site-specific treatments in maize.

\section{ACKNOWLEDGEMENTS}

Two anonymous referees are greatly acknowledge for helpful comments on the manuscript.

It is with regret that we report that Edite Sousa (1953 - 2010), friend, colleague and coauthor died in 2010.

\section{LITERATURE CITED}

BARROSO, J. et al. Spatial stability of Avena sterilis ssp. ludoviciana populations under annual applications of low rates of imazamethabenz. Weed Res., v. 44, n. 3, p. 178-186, 2004.

BARROSO, J. et al. Dispersal of Avena fatua and Avena sterilis patches by natural dissemination, soil tillage and combine harvesters. Weed Res., v. 46, n. 2, p. 118-128, 2006.

CARDINA J. et al. Analysis of Spatial Distribution of Common Lambsquarters (Chenopodium album) in No-Till Soybean (Glycine max). Weed Sci., v. 43, n. 2, p. 258-268, 1995.

COLBACH, N.; FORCELLA, F.; JONHSON, G. A. Spatial and temporal stability of weed populations over five years. Weed Sci., v. 48, n. 3, p. 366-377, 2000.
DERKSEN D. A. et al. Impacts of agronomic practices on weed communities: tillage systems. Weed Sci., v. 41, n. 3, p. 409-417, 1993.

DORADO, J. et al. Predicting weed emergence in maize crops under two contrasting climatic conditions. Weed Res., v. 49. n. 3, p. 251-260, 2009.

GONZÁLEZ-ANDÚJAR, J. L.; SAAVEDRA, M. Spatial distribution of annual grass weed populations in winter cereals. Crop Protec., v. 22, n. 4, p. 629-633, 2003.

GONZÁLEZ-ANDÚJAR J. L. et al. Spatial distribution and mapping of crenate broornrape infestations in continuous broad bean cropping. Weed Sci., v. 49, n. 6, p. 773-779, 2001.

HALSTEAD, S. J. et al. Geostatistical analysis of the weed seed bank. Proc. NCWSS. v. 45, n. 1, p. 123-124, 1990.

IZQUIERDO, J. et al. Spatial distribution of weed diversity within a cereal field . Agron. Sustainable Develop., v. 29, n. 3, p. 491-496, 2009.

JURADO-EXPÓSITO, M. et al. Multi-species weed spatial variability and site-specific management maps in cultivated sunflower. Weed Sci., v. 51, n. 3, p. 319-328, 2003.

LONGCHAMPS, L et al. Could weed sensing in corn interrows result in efficient weed control? Weed Technol., v. 26, n. 4, p. 649-656, 2012.

LÓPEZ-GRANADOS, F. Weed detection for site-specific weed management: mapping and real-time approaches.

Weed Res., v. 51, n. 1, p. 1-11, 2011.

MAUN, M. A.; BARRET, C. H. The biology of canadian weeds. 77 Echinochloa crus-galli (L.) Beauv. Canadian J. Plant Sci., v. 66, n. 3, p. 739-759, 1986.

MONQUERO, P. A. et al. Mapas de infestação de plantas daninhas em diferentes sistemas de colheita da cana-de-açúcar. Planta Daninha, v. 26, n. 1, p. 47-55, 2008.

RASMUSSEN, J. et al. Potential uses of small unmanned aircraft systems (UAS) in weed research. Weed Res., v. 53, n. 4, p. 242-249, 2013.

Planta Daninha, Viçosa-MG, v. 32, n. 2, p. 275-282, 2014 
SHIRATSUCHI, L. S. et al. Correlação da distribuição espacial do banco de sementes de plantas daninhas com a fertilidade dos solos. Planta Daninha, v. 23, n. 3, p. 429-436, 2005.

SYRJALA S. E. A statistical test for a difference between the spatial distributions of two populations. Ecology, v. 77, n. 1, p. 75-80, 1996.
WILES L. J. et al. Spatial distribution of broadleaf weeds in North Carolina Soybean (Glycine max) fields. Weed Sci., v. 40, n. 4, p. 554-557, 1992.

ZHANG, C.; KOVACS, J. M. The application of small unmanned aerial systems for precision agriculture: A review. Prec. Agric., v. 13, n. 6, p. 693-712, 2012. 